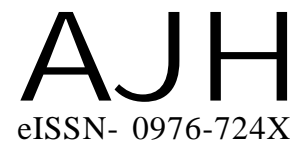

Received : 28.08.2017

Revised : 09.11.2017

Accepted : 16.11.2017

Members of the Research Forum

Associated Authors:

${ }^{1}$ Department of Horticulture,

College of Agriculture, Dr. B. S.

Konkan Krishi Vidyapeeth,

Dapoli, RATNAGIRI (M.S.) INDIA

Author for correspondence : B.M. RODGE

Department of Horticulture,

College of Agriculture, Dr. B. S.

Konkan Krishi Vidyapeeth,

Dapoli, RATNAGIRI (M.S.) INDIA

Email : balasahebrodge75

@ gmail.com
THEASIAN JOURNALOF HORTICULTURE

Volume 12 | Issue 2 | December, 2017 | 218-222

Visit us -www.researchjournal.co.in

RESEARCH PAPER

DOI : 10.15740/HAS/TAJH/12.2/218-222

\title{
Studies on effect of pruning on reproductive shoots and yield of mango cV. ALPHONSO
}

\section{B. M. RODGE AND K. H. PUJARI ${ }^{1}$}

ABSTRACT : The present investigation on studies on effect of pruning on reproductive shoots and yield of mango cv. ALPHONSO was carried out in the Department of Horticulture, College of Agriculture, Dr. B. S. Konkan Krishi Vidyapeeth, Dapoli, dist. Ratnagiri (M.S.), India, during 2007-2009. The indicated that the Smaximum length $(28.82 \mathrm{~cm})$ of reproductive shoot was recorded in 50\% current season pruning method carried out in third week of October and the lowest length of reproductive shoots $(4.66 \mathrm{~cm})$ was observed in current season pruning method carried out in first week of December. The mean of two years data indicated that the maximum fruit yield $(56.51 \mathrm{~kg}$ ) per tree was observed in $50 \%$ current season pruning method carried out in third week of October and the lowest fruit yield $(7.02 \mathrm{~kg})$ per tree was recorded in past season purning method carried out in first week of November.

KEY WORDS : Pruning, Shoot, Yield, Current season, Past season

HOW TO CITE THIS ARTICLE : Rodge, B.M. and Pujari, K.H. (2017). Studies on effect of pruning on reproductive shoots and yield of mango cv. ALPHONSO. Asian J. Hort., 12(2) : 218-222, DOI : 10.15740/HAS/TAJH/12.2/218-222. 